\title{
15th Nordic Symposium on Catalysis, Mariehamn, Åland, June 16-18, 2012
}

\author{
Dmitry Yu. Murzin · Päivi Mäki-Arvela • \\ Tapio Salmi
}

Published online: 16 April 2013

(c) Springer Science+Business Media New York 2013

The Nordic tradition in catalysis is rich, dating back to the time of the famous Swedish chemist Jöns Jacob Berzelius, who was the first to describe precisely the concept of catalysis in 1835 . An important milestone in the history of catalysis in FennoScandic area was in 1988, as Swedish scientists decided to transform the national Swedish symposium in catalysis to a Nordic symposium. The initiative was very fruitful, and 14 Nordic symposia took place in 1988-2010. The responsibility of the conference organization rotates between Denmark, Finland, Norway and Sweden.

Finnish scientists had the pleasure to host the 15th Nordic Symposium on Catalysis (www.nsc2012.org) in the ultramodern congress centre Alandica, in Mariehamn, Alland. For the first time in the history of Nordic symposia, we met on Aland islands, which are pearls of the archipelago between Finland and Sweden. Aland is one of the autonomous regions of Nordic countries.

The main topics of the symposium were 'Catalysis and sustainable development' and 'Catalysis in the Baltic Sea area'. The selection of these topics reflected global trends and local circumstances: the mankind faces one of its biggest challenges ever, when shifting from the use of fossil resources to renewable feedstock in the production of chemicals and fuel components. Environmental issues are crucial for the Baltic Sea region: Baltic Sea, being almost a closed lake, is surrounded by nine heavily industrialized countries, the region is rich in fauna and flora but a very woundable ecological system. Catalysis is one of the key technologies keeping the air clear and the water clean, providing the possibility for the unique nature to survive.

The 15th Nordic Symposium on Catalysis consisted of an ecological lecture, three plenary lectures, four Nordic keynote lectures, two industrial lectures, a Berzelius award lecture, 56 oral presentations and 91 posters. We were happy to receive participants from more than 25 countries, which reflected the real international dimension of the conference.

The participants were invited the possibility to submit article manuscripts based on their presentations. All manuscripts underwent a reviewing procedure and the result is this special issue, which reflects the state of art of catalysis not only in Nordic but also in global perspective. The Editors are grateful to Professor Gabor A. Somorjai for inviting us to prepare this special issue dedicated to the 15 th Nordic Symposium in Catalysis. We express our gratitude to the members of the Scientific and Organization Committees, to all the authors and reviewers for the extensive and qualified work.

The next Nordic Symposium on Catalysis will take place in Oslo, Norway in 2014. 